\title{
Benefits of entrepreneurship education and training for engineering students
}

\author{
Valentin Grecu ${ }^{1, *}$, and Calin Denes ${ }^{1}$ \\ ${ }^{1}$ Lucian Blaga University of Sibiu, Department of Industrial Engineering and Management, 550024, \\ 10 Victoriei Bd, Sibiu, Romania
}

\begin{abstract}
In the present economic situation, having knowledge of an academic subject is no longer sufficient for a new graduate. Students are increasingly required to have skills and abilities which will increase their employability, such as: the retrieval and handling of information; communication and presentation; planning and problem solving; and social development and interaction. Entrepreneurial education and training provides individuals with the ability to recognize commercial opportunities, self- esteem, knowledge and skills to act on them. It includes instruction in opportunity recognition, commercializing a concept, managing resources, and initiating a business venture. It also includes instruction in traditional business disciplines such as management, marketing, information systems and finance. Entrepreneurs or the move towards self- employment is, and will continue to become, an increasingly important element of economic growth and development. It is essential to have the infrastructure required to facilitate entrepreneurial mind-set and encourage self-employment. Having a culture of the creation of a new enterprise is a critical aspect of this infrastructure, as it will encourage students to take the risk of starting a business. The purpose of this paper is to describe the design and introduction of the entrepreneurial mindset for engineering students.
\end{abstract}

\section{The Challenges of the Global Economy}

Discoveries and inventions, revolutions and social movements have been the triggers of progress throughout history. Mankind has to face new challenges in the $21^{\text {st }}$ century such as globalization, the rapid pace of innovation, the fast spread of technology and its high speed adoption in our lives [1]. These factors and many others are changing not only how businesses and economies are functioning, but also the job market landscape. The knowledge and skills required by the present and future jobs are changing and consequently the education system at all levels has to respond and adapt to the new challenges [1].

Cheaper transportation and communication facilitate greater mobility and digital technologies support long distance exchange of large amounts of information, thus transforming the global labour markets. International migration used to be a one-way process, but especially for the ones with technical skills, it has become a reversible choice.

"Corresponding author: valentin.grecu@ulbsibiu.ro 
Scientists and engineers from developing countries are now able to work on increasingly complex tasks and collaborate with counterparts located at great distances and therefore they can contribute to their home economies while having social and professional connections in more advanced economies, without being forced to choose between settling abroad and returning home to far less attractive professional opportunities. Some even become 'transnational' as they work, and even maintain residences and citizenship, in more than one nation [2].

Given the dynamic economic context marked by profound and rapid changes, higher education institutions can no longer equip their graduates with all the knowledge and skills needed to perform in their professional life. Knowledge and skills needed for effectively functioning in a complex global world may be changing. In the information age, industries will have dynamic needs. According to Tony Dolphin [3], these drivers for change will continue "to cause dislocations and disruptions in the labour market", so that there will continue to be "fundamental shifts in the types of jobs that will be available and skills demanded by employers". The new jobs that will be created in the future will require individuals with "entrepreneurial, scientific, creative and emotional skills" [1,3].

\section{Understanding Entrepreneurship}

The link between economic growth and entrepreneurship has been highlighted by many studies and facts and this connection can easily be demonstrated also by common sense, economic observation or just by simple intuition: entrepreneurship is based on activities that convert ideas into economic opportunities. As a source of change and innovation, entrepreneurship boosts economic competitiveness and increases productivity [4].

The increasingly globalized world economy challenges organizations to increase competitiveness, productivity, flexibility and knowledge, factors that are closely associated with entrepreneurship. The OECD countries have experienced a shift in the structure of the industry between the late ' $70 \mathrm{~s}$ and early ' $90 \mathrm{~s}$, moving from concentration towards decentralization, indicating the development of entrepreneurship and the entrepreneurial mind-set. The assumption that supporting entrepreneurship is closely related with fostering a country's competitiveness appears today more valid than ever, given the technological change and the intensified global competition brought about by globalization and economic liberalization.

The fact that entrepreneurship is not a static phenomenon, but rather a dynamic process is demonstrated by most economic, psychological and sociological research on this topic [5]. Entrepreneurship is usually associated with issues related to decision making and represents more than just a mechanical economic factor.

The functional role of entrepreneurs is often highlighted in the existing definitions of entrepreneurship [6] and refer to decision making, allocating resources, coordination, supplying capital, bearing uncertainty and innovation [7-8]. Major schools of thought frequently associate these functional roles of the entrepreneurs with entrepreneurship:

- The Cantillon or Knightian entrepreneur is associated with risk seeking and is willing to take the risk associated with uncertainty

- The Schumpeterian entrepreneur is associated with innovation because he/she accelerates the generation, dissemination and application of innovative ideas

- The Kiznerian entrepreneur is associated with opportunity seeking, as he perceives end seizes new profit opportunities [9-10]

Entrepreneurship has undeniably impacted the world of business forever and has taken hold across the globe [11]. The powerful emergence of entrepreneurial activity in the U.S. in the past decade is just one example that supports this statement. Hundreds of thousands of small firms have been established each year. According to Kuratko [11], millions of new 
jobs have been created and for $94 \%$ of these new jobs are responsible $15 \%$ of the fastestgrowing new firms (i.e., "gazelles") and less than one third of these gazelles was involved in high technology [11]. Sixteen percent of all U.S. firms have been in existence for less than 1 year. Sixty-seven percent of all new inventions are created by smaller firms [12].

These facts prove that entrepreneurial firms are part of the process that re-defines the market economies. These small and medium sized enterprises play a crucial role in the innovations that lead to the growth of productivity and the changes in technology that redefined the market structure and therefore the competition. The market economies are always in the process of "becoming" as they are dynamic organic entities, being oriented towards the future, not focusing on the inheritance of the past [13].

Millions of people, including minorities, women and immigrants enter the economic mainstream through the entrepreneurial firms that enable them to access the pursuit of economic success. Entrepreneurship is crucial in this evolutionary process, playing an indispensable role of providing the "social glue" that connects "Main Street" activities and high-tech innovation [14].

\section{The Role of Education}

Education is the most effective means available to society to challenge the future [15]. Progress depends increasingly more on the capacities to research, innovate and adapt of the new generations. Without education, youth participation in the cultural and socio-economic life is impossible. Education will obviously not solve all the problems that humanity faces today, but it is essential in the effort to connect the members of the society, generate new relationships and respect to environmental needs [16].

School instruction, or formal education is not everything. Education also values the role of family and community and includes non-formal and informal sides. The immense community of educators is not being efficiently used to develop the entrepreneurial mindset for the younger generation, as they are a crucial human resource whose contribution can be useful in all local communities.

Entrepreneurship education has become popular for many reasons [17]. Learning about developing business plans and creating a company allows students to better understand and integrate finance, economics, accounting, marketing and other business disciplines, offering them an integrative and enriching educational experience. Entrepreneurship education encourages the founding of new businesses by students and alumni and equips them with critical decision-making skills that enhance the success of graduates in the job market. Furthermore, the entrepreneurial mind-set increases the transfer of technology to the market, from the university, through the development of technology-based business plans and student involvement with technology licensing. Finally, entrepreneurship education creates links between the academic and business communities. Education for entrepreneurship is considered a useful, applied approach to the study of business and the economy.

All these reasons are solid arguments for established entrepreneurs to support and fund entrepreneurship programs in universities and to get involved in developing the entrepreneurial eco-system in the community where they activate. Entrepreneurship offers also the possibility to experiment with pedagogy and curricula, as it is generally outside traditional discipline boundaries, allowing guest speakers and more practical and applied tasks. These experiments have also impacted and enhanced other business related courses, thus improving the experience of students. 


\section{The Entrepreneurial University}

As argued by Etzkowitz, Webster, Gebhart, and Terra [18], there is an increasing trend observed in universities around the world that aim to become entrepreneurial universities, incorporating the role of active contributors to the development of new companies in their local communities, in addition to their traditional role of scientific knowledge creators and educators Therefore, through their closer and more intense interaction with private industries and government institutions, universities become an increasingly important component of the national innovation system [19].

Interest for entrepreneurship education is more and more present among individuals outside the fields of business and engineering, although at first entrepreneurship education was firmly connected with these two fields [20]. Entrepreneurship education should be seen from a university-wide perspective and the increasing interest for this topic in a broader set of fields, combined with the enthusiasm of alumni from all fields to introduce a real-world dimension to their home schools encourages the implementation of the entrepreneurial mind-set throughout the whole campus. The gap between real-life situations and the classroom theories and concepts can be bridged with the help of entrepreneurship education for students with different specialization fields. Bringing students from non-business fields closer to the business school is the approach of some institutions that aim to educate students in an entrepreneurship classroom characterized by diversity. A different approach of university-wide entrepreneurship education consists of presenting lessons of entrepreneurship from within a specific field, thus giving a message relevant to the field itself.

As Streeter, Jaquette and Hovis [20] describe, there are more approaches of entrepreneurship and entrepreneurial education in universities. Streeter et al [20] recommend a radiant model of an entrepreneurial university, based on an extensive research. Such a model involves all stakeholders, being a more complex body of politics, academics, and finances. In order to move forward such a complex organism, the program leaders must coordinate and adjust the self-interests of individual stakeholders, thus creating a radiant program is a process that takes time. Even if the effort of each academic unit is only local, they must perceive that they can lay claim to the larger university-wide program.

However, the radiant model is rather difficult from an academic perspective. Finding justification in terms of curriculum and availability of the faculty to have entrepreneurship classes in non-business fields is challenging. The importance given to the bridge between the work world and the education and preparation phase is crucial for this justification. Not all majors accept that business education is useful and challenging for the graduates of those study fields. Therefore, the magnet model presented by Streeter et al [20] will be more likely to be maintained in higher education institutions that don't see entrepreneurship as rigorous outside business and/or engineering majors.

The model proposed in figure 1 focuses on a triple approach of the entrepreneurial university: an internal approach, an external approach and an operational one. The model highlights the importance of each of these three dimensions, acknowledging the need of having the appropriate infrastructure and creating a space for students to meet, interact and foster creativity and innovation. The external approach recognizes the role of the community in building an entrepreneurial ecosystem and the symbiotic relationship that the university should have with the business environment and the local community. The third approach described in the model, namely the operational one, is itself divided into three components that summarize the activities of a university: research, formal and informal teaching and learning. 


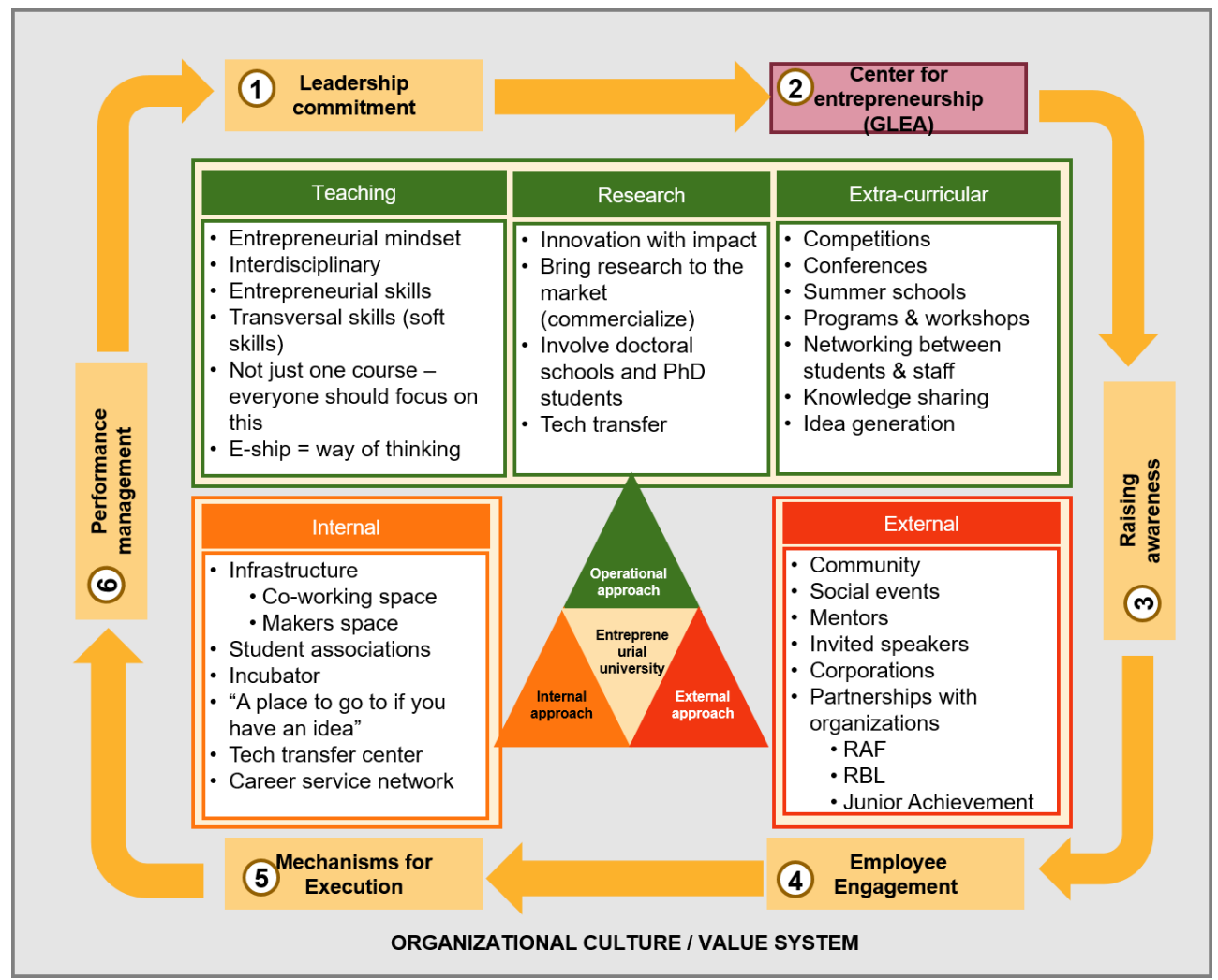

Fig. 1. Model of the entrepreneurial university.

The model presents also the steps that need to be followed in order to implement the entrepreneurial mind-set across the campus for achieving the radiant model of an entrepreneurial university. It all starts with the commitment of the leadership (university administrators). The following step is creating a structure that will coordinate and monitor the implementation of the measures needed to transform the university into an entrepreneurial one. Raising awareness of the importance of entrepreneurship, both for the economy and for the future of the university is an ongoing process and it should target students, alumni, faculty, administrative staff and the whole community and business environment. Engaging the employees in this process is a difficult task, but it is essential that everyone understands the short and long-term necessity of commitment towards entrepreneurship education. The mechanism of execution refers to offering all the stakeholders the necessary means to implement the plan to move forward towards a university-wide approach of entrepreneurship.

\section{Conclusions}

Regardless the approach, it is widely recognized that it is increasingly necessary for students to have transversal skills which will increase their employability. Entrepreneurial education equips students with abilities that increase their employment potential and include: the abilities to solve problems, to develop social interaction, abilities to find information and to handle it for decision making, planning, communication and presentation skills, etc. Entrepreneurial education and training provides individuals with the ability to recognize commercial opportunities, self- esteem, knowledge and skills to act on 
them. It includes instruction in opportunity recognition, commercializing a concept, managing resources, and initiating a business venture. Traditional business disciplines such as marketing, management, finance and information systems are also taught. Thus, the necessity of entrepreneurship education is undeniable.

Individuals must continuously improve their knowledge and skills as a response to today's rapid pace of change, otherwise economic stagnation will be in place. Training organizations, such as universities, find it difficult if not almost impossible to correlate their capacity to adapt the education and curricular offering with the pace of change in labour market needs. In a global, dynamic world it becomes more important that skills taught in schools are relevant for the workplace and are maintained and improved during the working life. Individuals can't afford anymore to stop their formal education once entering the labour market. Building a solid foundation of skills during school years and providing lifelong learning is probably the viable solution to reduce the skill gap [1].

A long-term strategy that involves governments, employers and educational institutions (like universities) is needed in order to reduce skill mismatch effectively. Only bringing together education and the working world can guarantee success. Individuals have to enter the job market with an appropriate, balanced mix of knowledge and skills that will allow over the professional life further education in order to cope with the new demands. There should be coherent guidance in choosing a career path, for a smooth transition from school to work and for skill improvement over the working life, to better exploit the skills of individuals and meet the needs of employers.

\section{References}

1. L. Ilie, I. Bondrea, Changing Labour Market Needs and the Challenges for Academic Leadership. In: ECMLG 2016-Proceedings of the 12th European Conference on Management, Leadership and Governance, 80 (2016)

2. A. Saxenian, International Mobility of Engineers and the Rise of Entrepreneurship in the Periphery. Research Paper, UNU-WIDER, United Nations University (UNU) 2006

3. T. Dolphin, (ed), Technology, globalization and the future of work in Europe: Essays on employment in a digitised economy, IPPR. http://www.ippr.org/publications/technologyglobalization-and-the-future-of-work-in-europe (2015)

4. S.E. Sanyang, H. Wen-Chi, International Entrepreneurship and Management Journal 6.3, 317$329(2010)$

5. A. Pirich, An interface between entrepreneurship and innovation: New Zealand SMEs perspective. Paper prepared for the 2001 DRUID Conference, Aalborg, Denmark (2001)

6. H. Barreto, (1989). The Entrepreneur in Microeconomic Theory: Disappearance and Explanation. London: Routledge.

7. C. Friijs, T. Paulsson and C. Karlsson, Entrepreneurship and Economic Growth: A Critical Review of Empirical and Theoretical Research. Östersund, Sweden: Institutet för tillväxtpolitiska studier (2002)

8. M. Jääskeläinen, Entrepreneurship and Economic Growth. Helsinki: Institute of Strategy and International Business (2000)

9. Organisation for Economic Co-operation and Development (OECD), Fostering Entrepreneurship. Paris: OECD (1998)

10. M. Carree, and A.R. Thurik,, International Handbook of Entrepreneurship Research, Boston/Dordrecht: Kluwer (Academic Publishers, 2003)

11. D.F. Kuratko, The emergence of entrepreneurship education: Development, trends, and challenges. Entrepreneurship theory and practice 29.5, 577-598 (2005)

12. P.D. Reynolds, M. Hay, \& S.M. Camp, Global entrepreneurship monitor. Kansas City, MO: Kauffman Center for Entrepreneurial Leadership (1999)

13. D.F. Kuratko, \& R.M. Hodgetts, Entrepreneurship: Theory, process, practice, (Mason, OH: South-Western College Publishers, 2004) 
14. Small Business, Administration, The new American revolution: The role and impact of small firms. Washington, DC: Small Business Administration, Office of Economic Research (1998).

15. UNESCO, Higher Education in the Twenty-first Century Vision and Action, World Conference on Higher Education, Paris (1998), retrieved 20.09.2010 from: http://unesdoc.unesco.org/images/0011/001163/116345e.pdf

16. C. Bucovală, Dezvoltarea durabilă a Mării Negre, (2009) retrieved 3.12 .2010 from http://lefo.ro/iwlearn/curriculum.html

17. A. Charney, and G.D. Libecap. Impact of entrepreneurship education. Kansas City, MO: Kauffman Center for Entrepreneurial Leadership (2000)

18. H. Etzkowitz, A. Webster, C. Gebhart, B.R.C. Terra, Research Policy, 29 (2), 313-330 (2000)

19. W. Poh-Kam, Y.P. Ho, and A. Singh, World Development 35.6 (2007), 941-958 (2007)

20. D.H. Streeter, J.P. Jaquette Jr, and K. Hovis, University-wide entrepreneurship education: Alternative models and current trends. No. 127271 (2002) 